\title{
EL REVERSO
}

Tiene estrategias que no conoces. Piensas que es una cuestión de docilidad y de dar la vuelta, pero no es así. No sabes qué verso desde el final de la página subirá hasta aquí para picarte los ojos. No trae idea de suicidio, no hereda los males visibles de tu casa. No tiene que ver con el miedo ni con los sueños en donde no llegas nunca a la estación.

El reverso se burla de tus sueños, de las rajaduras en el piso de tu casa y del temblor. Está aunque lo ignores. Entre el cuerpo de tu abuela y la sábana de flores. Entre su piel y la pijama que conserva su olor. El reverso no respira por ti ni por tus hermanos. Te ignora pero tú no debes ignorarlo a él.

¿Forma parte de una fibra en tu corazón? ¿Está parado en la fila del colegio? Se ríe de tus decisiones pero no es el mal. Posibilita lo que no concebías y no daña con ello. No aumenta la creciente del río, no se lamenta, no tiene prisa, no se esconde bajo tu chamarra de cuero. No se anuncia y no tiene lista de verbos favoritos. No te condiciona pero tampoco te mira como crees.

Si fuera silencio habría tapado tu boca, tampoco es sorpresa. Es lo que es. No la parte interna del cuenco ni su base, tampoco los poros fríos en la cerámica. No se manifiesta visiblemente pero no hay molécula ni mínima constitución que desconozca. No está bajo la tapa ni en la parte posterior del ojo. No ubica el nervio óptico, no invierte ninguna imagen.

No opaca la piel de las manzanas. Consume la cera de las velas. Se traga las horas con gula y confía demasiado en su imagen.

¿Tiene oído para los pájaros? ¿Le importa tu propio tiempo? ¿La profunda gana de crecer del tabachín? ¿Leerá la línea de Malinowsky dibujada en el muro de tu casa?:

Se acordará el viento de la hierba y de nosotros. 
El reverso no distingue gama de grises. No puede diferenciar entre el grafito y la tinta china. Le dan igual las sombras. No le incomoda el negro de los funerales, no conoce el peso de los hombros. Nunca ha visto un bulto lanzarse por la ventana. No tiene iniciativa, tampoco voluntad. No escribe malos poemas ni poéticas para despertar a Li Po. No fabrica nada mal hecho, no acumula ni guarda nada para sí. Permite que te veas de otro modo. No conoce la bondad pero quizá intervenga en el crecimiento. No tiene culpa ni compromiso. Conoce al derecho y al revés tu casa. Cada uno de tus pensamientos, pero no los atesora ni los aborrece.

El reverso te sostiene pero no moldea tu gravedad. Va a contratiempo. No le preocupa la eternidad, un goteo mal arreglado en la cocina. Tampoco la cara leal de tus amigos. No está oculto a tus ojos, pero nada de tus pertenencias le conviene. Tampoco le interesa el pan que no vendes, el que se endurece; ni la madera que astilló tus dedos ni los actos que te pusieron el gesto rudo. No sabe de cuerpos adheridos ni de heridas que se distienden. No tiene principio ni fin. Tampoco se enreda en la mitología. No se anuncia en visiones y jamás conoció el rostro de Blake. No guió ninguno de sus carbones. No caligrafió ninguno de sus textos, no lamió nunca su torso.

No sabe nunca cómo detenerse.

(Del libro Parcela blanca) 